\title{
Biliary Excretion of Lead in the Rat
}

\author{
N. CASTELlinO, P. LAMANNA, and B. GRIECO \\ From the Institute of Industrial Medicine of the University, Naples
}

Studies have been made in the rat of the elimination of ${ }^{210} \mathrm{~Pb}$ in the bile after the intravenous injection of $100 \mu \mathrm{g}$. of lead.

Four groups of rats were used: in two the bile was drained by cannulation of the bile duct, and in the other two the bile flow to the duodenum was interrupted by ligation or division of the bile duct. The radioactivity of the bile, of the intestinal walls, and of the intestinal contents and faeces was determined.

The results showed that lead is eliminated from the liver mainly by the bile, thus excluding passage through the intestinal walls into the faeces as important under these conditions.

\section{Biliary Excretion of Lead in the Rat}

Clinical and experimental evidence agree in showing that lead is excreted in the urine and faeces, but it is not clear how lead reaches the faeces. The high percentage of lead bound to the liver and the elimination of lead via the intestine suggest that it is excreted in the bile, as has been directly demonstrated by Blaxter and Cowie (1946) in the sheep. In the rat, the results of a study on the distribution and excretion of ${ }^{210} \mathrm{~Pb}$ (Castellino and Aloj, 1964) also favour this route, since 24 hours after an intravenous injection of ${ }^{210} \mathrm{~Pb}$ the hepatic concentration is greatly reduced, and a high proportion appears in the faeces.

Massione (194I) and Witschi (1964), on the contrary, produced evidence that lead could be excreted through the intestinal walls. Witschi (1964) suggested that in rats lead, probably bound to seralbumins, passes directly from the blood into the intestinal canal, where the metal is liberated by the action of proteolytic enzymes.

The present work was designed to demonstrate the direct biliary excretion of lead and to examine the possibility of the passage of the metal into the faeces through the intestinal walls.

\section{Methods}

Animals Twenty Wistar male rats weighing $285 \mathrm{~g}$. (250 to $330 \mathrm{~g}$.) were used.

Tracer Compound ${ }^{210} \mathrm{~Pb}$ acetate was supplied by the Radiochemical Centre, Amersham, Great Britain,

Received for publication April 6, 1966. with a specific activity of $50 \mathrm{mc}$. $/$ mmole. For injection this was diluted with $0.000 \mathrm{I} N$ acetic acid. Activity determinations were carried out with a well-type crystal scintillation counter ${ }^{\star}$ by estimating the $\gamma$ emission of ${ }^{210} \mathrm{~Pb}$. This is a weak radiation $(0.047 \mathrm{MeV})$ and efficiencies were about $2 \%$.

Treatment of Rats Injections were given into the femoral vein under ether anaesthesia. Each rat was given $0.2 \mathrm{ml}$. of lead acetate solution, $\mathrm{pH} 4.7$, containing I00 $\mu \mathrm{g}$. of lead and enough ${ }^{210} \mathrm{~Pb}$ to record about $10^{\circ}$ counts/minute.

The animals were divided into four groups. In the first and second, each comprising six rats, the bile was drained by cannulation of the biliary duct. In the first group ${ }^{210} \mathrm{~Pb}$ was injected immediately after cannulation; in the second, eight days before cannulation. After cannulation the rats were put into restraining cages with access to food and drink. They were observed for 50 hours. The bile, which flowed continuously, was collected at regular intervals of 30 and 60 minutes during the day and for 12 hours during the night. For each sample of bile we measured the rate of biliary flow and the rate of ${ }^{210} \mathrm{~Pb}$ excretion.

At the end of the experiment the animals were killed and the intestinal tract-from duodenum to anal orificewas removed. The intestinal walls and the intestinal contents (washed out with water) and the faeces excreted during the experiment were hydrolysed separately in hot $33 \% \mathrm{NaOH}$, and the ${ }^{210} \mathrm{~Pb}$ was estimated.

In the third and fourth groups, each comprising four rats, the flow of bile was interrupted by a double ligature of the biliary duct where it joins the duodenum (third group) or by complete cutting of the biliary duct (fourth group). The ${ }^{210} \mathrm{~Pb}$ was administered at the end of the operation. The animals were kept under observation in single cages for separate collection of the urine and faeces

\footnotetext{
* Nuclear, Chicago.
} 

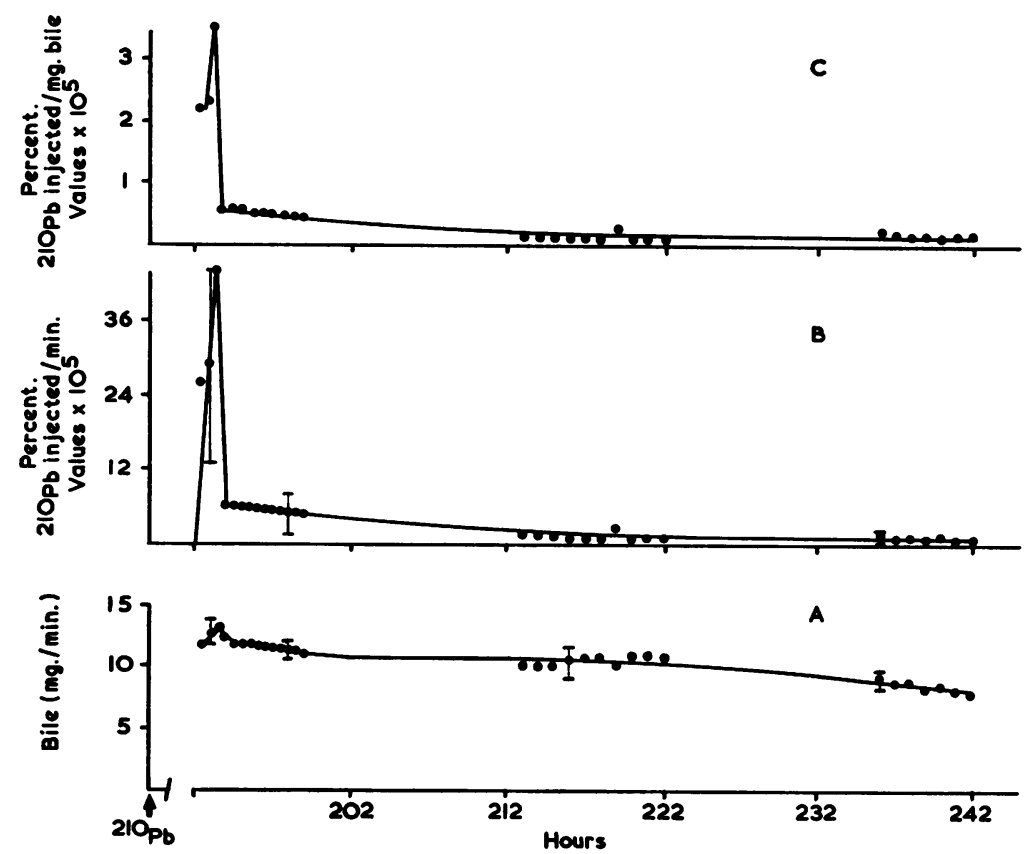

FIG. 2. Second group of rats: biliary excretion of ${ }^{210} \mathrm{~Pb}$. 
TABLE

\begin{tabular}{|c|c|c|c|c|c|}
\hline \multirow{3}{*}{ Group } & \multirow{3}{*}{ Urine } & \multicolumn{3}{|c|}{${ }^{210} \mathrm{~Pb}$ in Percentage of INJECted Dose } & \\
\hline & & Faeces & Bile & & \\
\hline & & & & Walls & Contents \\
\hline$I_{\text {(6 rats) }}$ & - & - & $\begin{array}{l}8 \cdot 4 \\
(6 \cdot 4-1 I \cdot 5)\end{array}$ & $\begin{array}{l}0.36 \\
(0.14-0.72)\end{array}$ & $\begin{array}{l}0.09 \\
(0 \cdot 3-0 \cdot 16)\end{array}$ \\
\hline $\begin{array}{l}\text { II } \\
\text { (6 rats) }\end{array}$ & - & - & $\begin{array}{l}0.068 \\
(0.037-0.89)\end{array}$ & $\begin{array}{l}0.06 \\
(0-0.10)\end{array}$ & $\begin{array}{l}0.22 \\
(0.14-0.37)\end{array}$ \\
\hline $\begin{array}{l}\text { III } \\
\text { (4 rats) }\end{array}$ & $\begin{array}{l}3 \cdot 60 \\
(2 \cdot 4-5 \cdot 1)\end{array}$ & $\begin{array}{l}0.61 \\
(0-1 \cdot 4)\end{array}$ & - & $\begin{array}{l}0.63 \\
(0.42-0.94)\end{array}$ & $\begin{array}{l}0.8 \mathrm{I} \\
(0 \cdot 35-\mathrm{I} \cdot 20)\end{array}$ \\
\hline $\mathrm{IV}_{(4 \text { rats })}$ & $\begin{array}{l}2 \cdot 95 \\
(1 \cdot 0-4 \cdot 3)\end{array}$ & $\begin{array}{l}0.12 \\
(0-0.62)\end{array}$ & - & $\begin{array}{l}0.45 \\
(0.28-0.56)\end{array}$ & $\begin{array}{l}0.24 \\
(0.08-0.47)\end{array}$ \\
\hline
\end{tabular}

Means and ranges are reported.

and were killed 48 hours later. Analyses of faeces, etc., were carried out as before.

\section{Results}

The results obtained in the two groups of cannulated rats are given in Figures $I$ and 2. Although the bile flow was almost constant at about ro mg./ min., the elimination of ${ }^{210} \mathrm{~Pb}$ was irregular. In both groups, the ${ }^{210} \mathrm{~Pb}$ excretion curves show an initial peak followed by a progressive and slow fall. The initial peak ( 30 to 60 minutes after the operation) is hard to interpret. The subsequent failure to maintain a steady rate of excretion is probably a consequence of the hepatic binding of lead, liver damage caused by the cannulation, and the toxic action of the anaesthetics.

Fifty hours after the operation the biliary excretion of lead totalled $8.4 \%$ of the administered dose (fiducial limits 4.7 to $12.1 \%$ ) in the first group, injected after cannulation, and $0.068 \%$ (fiducial limits 0.003 to $0.1 \%$ ) in the second group, injected eight days before cannulation.

In rats injected immediately after cannulation, very little lead-only $0.09 \%$ of the injected dosewas recovered in the intestinal contents and faeces (Table). Thus little lead passed directly through the intestinal walls. In rats injected before cannulation, the lead recovered in the intestinal contents and faeces was similar to that excreted at the corresponding time in the faeces of uncannulated rats (Casteilino and Aloj, 1964) and probably represents holdup in the intestinal canal at the time of cannulation.

The results with the third and fourth groups of rats, with ligated or divided bile ducts, are shown in the Table. Very little ${ }^{210} \mathrm{~Pb}$ was present in the intestinal contents and faeces.

\section{Discussion}

Blaxter and Cowie (1946) showed that in sheep given $150 \mathrm{mg}$. lead acetate $7.5 \%$ of the dose was excreted in six days. Of this, $17 \%$ was excreted in the urine, $81 \%$ in bile, and $2 \%$ in faeces.

Our results in the rat are in agreement. From rats with bile ducts cannulated just before the intravenous injection of ${ }^{210} \mathrm{~Pb}$ only $0.09 \%$ of the dose was excreted into the gastro-intestinal tract, whereas $8.4 \%$ was excreted in bile. Interruption of the biliary flow by ligation or division of the bile duct also stopped the appearance of ${ }^{210} \mathrm{~Pb}$ in the gastrointestinal tract. These results contradict the conclusions reached by Massione (I94I) and Witschi (1964) that lead is excreted, to a considerable extent, directly through the walls of the intestines. Under our experimental conditions this type of excretion is negligible. The excretion in the bile accords well with the reduction in hepatic lead concentration in uncannulated rats observed by Castellino and Aloj (r964).

We cannot conclude with certainty that lead only appears in the gastro-intestinal tract from bile, since excretion in bile in these experiments was considerably less than that in faeces in uncannulated rats (Castellino and Aloj, 1964). This may, of course, be due to the surgical intervention and the consequent metabolic disturbance. Nevertheless, it is considered likely that the bile is an important carrier of lead in the rat.

\section{REFERENCES}

Blaxter, K. L., and Cowie, A. T. (1946). Nature, 157, 588. Castellino, N., and Aloj, S. (1964). Brit. F. industr. Med., 21, 308.

Massione, R. (194I). Med. d. Lavoro, 32, 149.

Witschi, H. P. (1964). Int. Arch. Gewerpath. Gewerbehyg., 20, 449. 